\title{
Biological ageing is a key determinant in systemic sclerosis
}

\author{
Paul G Shiels ${ }^{2 *}$, JCA Broen ${ }^{1,2}$, LM McGlynn², J Thomson², MM Chee ${ }^{2}$, R Madhok $^{3}$, TRDJ Radstake ${ }^{1}$ \\ From 6th European Workshop on Immune-Mediated Inflammatory Diseases \\ Nice, France. 23-25 November 2011
}

\section{Background}

Systemic sclerosis (SSc) is an autoimmune disease characterized by vasculopathy, immune cell activation and fibrosis of the skin and internal organs, occurring mainly in females. Although a lot of progress has been made in the discovery of genetic risk factors for SSc, environmental factors triggering onset of SSc have not been identified. This provides a foundation for the involvement of processes related to biological ageing to trigger SSc onset and perpetuation in the genetically susceptible host. Consequently, we have investigated key determinants of biological ageing, namely telomere attrition and the role of telosome proteins in the pathology of systemic sclerosis and how it impacts on individual leukocyte cell subsets.

Epigenetic processes, such as telomere attrition have been implicated in SSc [1]. The length of telomeric DNA repeats shortens during replicative ageing of peripheral blood lymphocytes. This process is exacerbated by psychological, sociological and biological determinants [2,3]. As a consequence, telomere length reflects the "miles on the clock" of a given cell type. Proteinaceous components of the associatedtelosome arecomplicit in the sensing, signaling and repair of DNA damage [3]. These have a critical role inprotectingthe cell from excessive DNA damage, by facilitating cellular senescence and apoptosis.

This study aimed to evaluate telosome biologyin an independent, clinically well-defined SSc cohorts. Moreover, we aimed to investigate whether there are differences in telomere attrition between different immune cell subsets and if these differences are accompanied by changes in expression of genes involved in telomere functioning.

\section{Materials and methods}

Telomere lengths were determine by Q-PCR [4] and telosome transcript expression levels measured by

\footnotetext{
${ }^{2}$ University of Glasgow, MVLS, Glasgow, UK

Full list of author information is available at the end of the article
}

RT-PCR [4].Statistical analyses were undertaken to investigate the association between telomere lengths, telosome transcript levels and clinico-pathological features of the disease, in peripheral blood leukocytes individual leukocyte subsets.

\section{Results}

We observed significant telomere attrition with increasing chronological age in a control population $(\mathrm{p}<0.009$; $\mathrm{n}=$ 382) but not in dcSSc samples from independent Dutch $(n=143)$ and UK cohorts $(n=160)$. Despite this, dcSSc telomere lengths were on average shorter than controls at any given chronological age, reflecting more miles on the clock with the disease state. We also observed dcSSc specific telomere shortening in $\mathrm{pDCs}(\mathrm{p}=0.001)$ compared to controls. This shortening was not further accelerated with increasing chronological age.

Analysis of the telosome, indicated significant expression changes in six key proteins relating to DNA repair and telosome stability and regulation $(\mathrm{p}<0.01)$.

\section{Conclusions}

We have demonstrated that dcSSc exhibits features consistent with accelerated biological ageing. This process appears to be independent of increasing chronological age, indicative of aberrant telosome biology with disease preempting the development of clinical symptoms at a later chronological date. Our data have provided novel insight into the pathogenesis of dcSSC and identified new targets for therapeutic intervention. They have also confirmed pDCs as an important cell type in dcSSc pathogenesis.

\footnotetext{
Author details

'Dept. of Rheumatology, Radboud University Medical Center, Nijmegen, The Netherlands. ${ }^{2}$ University of Glasgow, MVLS, Glasgow, UK. ${ }^{3}$ Dept. Rheumatology, Glasgow Royal Infirmary, Glasgow, UK.
}

Published: 23 November 2011 


\section{References}

1. Maclntyre A, et al: Association of increased telomere lengths in limited scleroderma, with a lack of age-related telomere erosion. Annals of the Rheumatic Diseases 2008, 67(12):1780-1782.

2. Lamb KJ, Shiels PG: Telomeres, ageing and oxidation. In Redox Metabolism and Longevity Relationships in Animals and Plants. Series: SEB experimental biology series (62). Taylor and Francis, New York, USA;Foyer CH, Faragher R, Thornally PJ 2009:117-137.

3. Shiels PG, et al: Accelerated Telomere Attrition Is Associated with Relative Household Income, Diet and Inflammation in the pSoBid Cohort. PLOS One 2011, 6(7):e22521, Epub 2011.

4. McGlynn LM, et al: Cellular senescence in pretransplant renal biopsies predicts postoperative organ function. Aging Cell 2009, 8(1):45-51.

doi:10.1186/1479-5876-9-S2-17

Cite this article as: Shiels et al:: Biological ageing is a key determinant

in systemic sclerosis. Journal of Translational Medicine 2011 9(Suppl 2):17.

\section{Submit your next manuscript to BioMed Central} and take full advantage of:

- Convenient online submission

- Thorough peer review

- No space constraints or color figure charges

- Immediate publication on acceptance

- Inclusion in PubMed, CAS, Scopus and Google Scholar

- Research which is freely available for redistribution

Submit your manuscript at www.biomedcentral.com/submit 